\title{
Elżbieta Majchrowska
}

Krakowska Akademia im. Andrzeja Frycza Modrzewskiego

e-mail: emajchrowska@afm.edu.pl

\section{PERSPEKTYWY ROZWOJU STOSUNKÓW \\ HANDLOWYCH POLSKI Z KANADA W ŚWIETLE UMOWY CETA}

\section{PROSPECTS OF DEVELOPMENT \\ OF TRADE RELATIONS BETWEEN POLAND AND CANADA IN THE LIGHT OF CETA}

DOI: 10.15611/pn.2017.498.17

JEL Classification: F13, F15

Streszczenie: Trwające ponad pięć lat negocjacje w sprawie umowy CETA (Comprehensive Economic Trade Agreement) między UE a Kanadą zaowocowały podpisaniem porozumienia z końcem 2016 r. Wynikająca z umowy planowana eliminacja barier taryfowych oraz pozataryfowych w przywozie do Kanady może okazać się bardzo korzystna dla unijnych, w tym polskich, eksporterów i przyczynić się do rozwoju polsko-kanadyjskich stosunków handlowych. Przemawia za tym fakt, że wielkość wymiany handlowej Polski z Kanadą sukcesywnie wzrasta, a pozycja Polski jest w tym zakresie bardziej znacząca niż pozostałych państw członkowskich UE z Europy Środkowo-Wschodniej. Dla Polski Kanada jest zatem istotnym partnerem handlowym, szczególnie ze względu na potencjalny wzrost polskiego eksportu. $\mathrm{Na}$ uwagę zasługuje również fakt, że w strategii Global Markets Action Plan na lata 2015-2017 Polska została wskazana przez rząd Kanady jako priorytetowy oraz perspektywiczny rynek w zakresie możliwości rozwoju dwustronnej współpracy gospodarczej.

Słowa kluczowe: CETA, RTA, Kanada, Polska, UE.

Summary: The negotiations on the Comprehensive Economic Trade Agreement between the EU and Canada, which had been in progress for five years, resulted in signing the agreement at the end of 2016. The planned elimination of tariff and non-tariff barriers on exports to Canada, which results from the signed agreement, may prove to be very beneficial for EU, including Polish, exporters and may contribute to the development of Polish-Canadian trade relations. This claim is supported by the fact that the Poland-Canada trade volume has been increasing gradually and Poland's position in this regard is more prominent as compared to other EU Member States from the Central Eastern Europe. Canada is, thus, a key trade partner for Poland, particularly in the context of the expected, potential increase of Polish exports. It is also worth pointing out that Poland was indicated in the 2015-2017 Global Markets Action Plan as a priority and prospective market for Canada in terms of opportunities for the development of bilateral trade.

Keywords: CETA, RTA, Canada, Poland, EU. 


\section{Wstęp}

Dynamika zmian zachodzących w gospodarce światowej uległa w ostatnich dekadach zdecydowanej intensyfikacji, a system handlu światowego podlega już od pewnego czasu głębokim przekształceniom. Należą do nich np. nasilające się tendencje integracyjne jako skutek m.in. niepowodzeń na forum Światowej Organizacji Handlu (WTO), a trudny do zażegnania impas od lat skłania wiele państw do podejmowania alternatywnych zabiegów i zabezpieczania swoich interesów handlowych. Głównie dlatego, szczególnie od przełomu wieków, obserwujemy istotne namnożenie inicjatyw integracyjnych, głównie w postaci dwu- lub kilkustronnych regionalnych porozumień handlowych $^{1}$ (Regional Trade Agreements - RTAs), w ramach których ma miejsce szersza i bardziej kompleksowa liberalizacja handlu niż ta, która odbywa się na forum WTO. Dlatego też w miejsce klasycznych stref wolnego handlu powstają bardziej zaawansowane porozumienia o szerszym zakresie. Są wśród nich umowy handlowe nowej generacji, które Unia Europejska, poszukując alternatywnych możliwości korzystniejszego dostępu do innych rynków, zawiera ze swoimi partnerami. Szczególnie istotna jest w tym kontekście Kompleksowa umowa gospodarczo-handlowa pomiędzy Unią Europejską a Kanadą (Comprehensive Economic Trade Agreement - CETA), która, poprzez ugruntowanie współpracy między jej stronami, może przyczynić się do zwiększenia wzajemnych obrotów handlowych, co jest szczególnie ważne z punktu widzenia polskich eksporterów. Nowego wymiaru nabierają zatem w tym kontekście perspektywy rozwoju stosunków handlowych Polski, jako członka UE, z Kanadą. Przedstawienie ich dalszego rozwoju, w świetle zapisów nowego porozumienia, jest celem niniejszego opracowania. Ważne tło dla badań stanowiła zatem analiza wzajemnych obrotów handlowych. Z uwagi na rozległość oraz złożoność tematyki autorka skupiła się na wybranych aspektach badanego problemu. Rozważania przedstawione w opracowaniu zostały przeprowadzone w szczególności w oparciu o analizę umowy [CETA 2017] oraz materiałów Ministerstwa Rozwoju, Komisji Europejskiej i WTO. Metoda badawcza wykorzystana w artykule odnosi się więc głównie do analizy źródeł wtórnego prawa UE oraz danych statystycznych pochodzących z raportów KE, WTO oraz urzędów administracji rządowej.

\section{Obroty handlowe Polski z Kanadą - wielkość, dynamika i struktura}

Dla przedstawienia perspektyw rozwoju stosunków handlowych Polski z Kanadą istotne jest nakreślenie tła w postaci wielkości, dynamiki oraz struktury towarowej wzajemnych obrotów handlowych. Na tej podstawie można będzie określić poten-

${ }^{1} \mathrm{~W}$ pierwszym kwartale $2017 \mathrm{r}$. WTO odnotowała łącznie prawie 650 notyfikacji dotyczących RTAs, z czego ponad 430 weszło w życie i obowiązuje. Należy podkreślić, że obecnie wszyscy członkowie tej organizacji należą do co najmniej jednego porozumienia handlowego. Zob.: [WTO, Facts and figures; WTO RTA-IS]. 
cjalne korzyści wynikające z zapisanych w umowie CETA obniżek stawek celnych oraz eliminacji barier o charakterze pozataryfowym.

W 2016 r. Kanada jako partner handlowy UE zajęła 10. miejsce ${ }^{2}$ pod względem obrotów ogółem (z udziałem nieprzekraczającym $2 \%$ w całym handlu zewnętrznym UE) [European Commission 2017]. Należy podkreślić, że towarowe obroty handlowe UE z Kanadą są mocno skoncentrowane geograficznie ${ }^{3}$, a około $90 \%$ towarów importowanych oraz eksportowanych przez UE z/do Kanady stanowią towary przemysłowe [MADB]. Na tym właśnie tle istotne jest przedstawienie pozycji Polski jako partnera handlowego Kanady i miejsca, które Polska zajmuje w tym zakresie wśród państw członkowskich UE. Jeśli chodzi o grupę unijnych eksporterów, mieściła się ona w ostatnich latach w pierwszej dziesiątce, jednak w gronie krajów Europy Środkowej i Wschodniej, będących członkami UE, Polska zajmuje zdecydowanie pozycję lidera. Szczegóły prezentuje tabela 1.

Tabela 1. Udział Polski w unijnym eksporcie do Kanady na tle członków UE z grupy krajów EŚW (2016 r., w \%)

\begin{tabular}{|c|c|c|c|c|c|c|c|c|c|c|c|}
\hline $\begin{array}{l}\text { i } \\
\text { Iు }\end{array}$ & 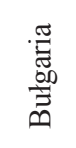 & 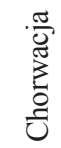 & $\begin{array}{l}\text { त्रू. } \\
\text { J }\end{array}$ & 㥯 & 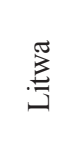 & بَّ & $\begin{array}{l}\frac{\pi}{4} \\
\frac{5}{0}\end{array}$ & 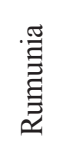 & 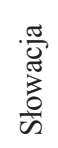 & 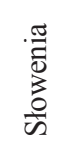 & $\begin{array}{l}\vec{D}_{0} \\
3^{\infty}\end{array}$ \\
\hline 100 & 0,1 & 0,1 & 0,6 & 0,25 & 0,16 & 0,05 & 3,5 & 0,3 & 0,7 & 0,2 & 0,4 \\
\hline
\end{tabular}

Źródło: opracowanie własne na podstawie [MADB].

Udział Polski w roku 2016 był zdecydowanie najwyższy w tej grupie państw. Należy podkreślić, że ulega on również stopniowemu wzrostowi - w stosunku do roku 2012 wzrósł o 1,2 pkt proc. Jeśli chodzi natomiast o import z Kanady to podobnie jak w eksporcie pozycja Polski była wyższa niż innych państw EŚW, jednak ogółem wśród członków UE zajęła ona 15. pozycję w roku 2016 (spadek o jedno miejsce w stosunku do roku poprzedniego) [MADB].

\footnotetext{
${ }^{2}$ Unia zajęła wówczas drugie, po USA, miejsce wśród partnerów handlowych Kanady, z analogicznym udziałem na poziomie 9,6\%. Wartość towarowych obrotów handlowych UE z Kanadą wyniosła w 2016 r. nieco ponad 64 mld euro. We wzajemnych stosunkach handlowych między Unią Europejską a Kanadą istotnym czynnikiem jest również wymiana usługowa. Dla Kanady Unia Europejska jako blok jest drugim po Stanach Zjednoczonych najważniejszym partnerem w wymianie usługowej (w 2015 r. wartość tej wymiany według danych Eurostatu przekroczyła $30 \mathrm{mld}$ euro). W obrocie usługami między Kanadą a UE dominują: usługi transportowe, podróże, ubezpieczenia i usługi komunikacyjne [European Commission 2017].

${ }^{3}$ Eksport zaledwie pięciu krajów stanowił w ostatnich latach około $70 \%$ unijnego eksportu do Kanady ogółem, z czego prawie $30 \%$ przypadało na Niemcy (ponad $27 \%$ w roku 2016). Jeśli chodzi o import z Kanady zakres koncentracji geograficznej był jeszcze wyższy za sprawą Wielkiej Brytanii (ponad 42\% udziału w 2016 r.).
} 
W 2016 r. Kanada zajęła 25. miejsce wśród polskich rynków eksportowych (udział $0,68 \%$, awans o 1 pozycję w stosunku do roku poprzedniego), w imporcie była to pozycja 46. (udział 0,18\%, również awans o jedną pozycję). Jednak dla Polski Kanada jest istotnym partnerem handlowym ze względu na oczekiwane zwiększenie polskiego eksportu. Przemawia za tym systematyczny wzrost wielkości wymiany handlowej między tymi partnerami w ostatnich latach, co zostało szczegółowo zestawione w tabeli 2.

Tabela 2. Wymiana handlowa Polski z Kanadą w latach 2010-2016 (mln EUR)

\begin{tabular}{|l|c|c|c|c|c|c|c|}
\hline Wyszczególnienie & 2010 & 2011 & 2012 & 2013 & 2014 & \multicolumn{1}{c|}{2015} & 2016 \\
\hline Eksport & 698,05 & 572,99 & 728,40 & 759,10 & 947,39 & 1115,77 & 1248,94 \\
\hline Import & 401,09 & 225,49 & 407,34 & 301,36 & 309,50 & 334,82 & 330,25 \\
\hline Obroty łącznie & 1099,14 & 798,48 & 1135,74 & 1060,46 & 1256,89 & 1450,59 & 1579,19 \\
\hline Saldo & 296,96 & 347,5 & 321,06 & 457,74 & 637,89 & 780,95 & 918,69 \\
\hline
\end{tabular}

Źródło: opracowanie własne na podstawie [Insigos 2017].

W roku 2016 Polska odnotowała stosunkowo korzystne wyniki obrotów handlowych z Kanadą4. Ze względu na dynamiczny wzrost eksportu (o prawie 12\%), przy jednoczesnym spadku importu o ok. 1,4\%, dodatnie saldo wzrosło do prawie 0,92 mld EUR. Analizując dostępne dane za pierwszy kwartał 2017 r., również można potwierdzić tendencję wzrostową. W stosunku do analogicznego okresu roku poprzedniego w eksporcie do Kanady odnotowano wzrost na poziomie ponad 6\%, a w imporcie aż o 65\%. Po 3 miesiącach 2017 r. wartość polsko-kanadyjskich obrotów handlowych wyniosła 502,72 mln EUR, wykazując wzrost w stosunku do tego samego okresu z 2016 r. o prawie 20\% (eksport z Polski do Kanady wyniósł 345,6 mln EUR, a import osiągnął 157,1 mln EUR) [Insigos 2017].

Podobnie jak w przypadku całej UE, w strukturze towarowej wymiany handlowej Polski i Kanady dominują towary przemysłowe ${ }^{5}$. Udział pięciu wymienionych niżej grup produktów stanowił w 2016 r. ponad 70\% polskiego importu z Kanady oraz odpowiednio ponad $80 \%$ eksportu do Kanady.

${ }^{4}$ Inaczej niż w przypadku krajów UE (ponad 4-krotnie wolniejszy wzrost eksportu, tj. o 2,6\%), rok 2016 zaowocował intensyfikacją wywozu do innych krajów rozwiniętych (spoza UE) - wzrost ogółem o 5,6\%. Wynikało to zasadniczo ze zwiększenia eksportu do USA (o 7,8\%), Kanady (o ok. 12\%) oraz Szwajcarii (o 8,4\%). Por.: [Ocena sytuacji w handlu...].

${ }^{5} \mathrm{~W}$ strukturze towarowej importu z Kanady do UE kluczowe miejsce zajmują: perły, kamienie szlachetne i artykuły z nich wytwarzane, maszyny i urządzenia mechaniczne, produkty mineralne, pojazdy i sprzęt transportowy oraz produkty chemiczne. Udział wymienionych grup produktów stanowił w 2016 r. prawie 76\% całkowitego unijnego importu z Kanady. Te same cztery grupy dominują po stronie unijnego eksportu do Kanady, przy czym istotną pozycję zajęły też produkty sekcji IV HS Gotowe artykuły spożywcze, napoje, tytoń [European Commission 2017]. 
Tabela 3. Struktura towarowa obrotów handlowych Polski z Kanadą według pięciu najważniejszych grup produktów (wg sekcji CN) w roku 2015

\begin{tabular}{|l|c|c|l|c|c|}
\hline \multicolumn{1}{|c|}{ Import z Kanady } & \multicolumn{3}{c|}{ Eksport do Kanady } \\
\hline \multicolumn{1}{|c|}{ sekcja CN } & $\begin{array}{c}\text { wartość } \\
\text { w mln } \\
\text { EUR }\end{array}$ & $\begin{array}{c}\text { udział } \\
\text { w \% }\end{array}$ & \multicolumn{1}{|c|}{ sekcja CN } & $\begin{array}{c}\text { wartość } \\
\text { w mln } \\
\text { EUR }\end{array}$ & $\begin{array}{c}\text { udział } \\
\text { w \% }\end{array}$ \\
\hline $\begin{array}{l}\text { XVI Maszyny i urządzenia, } \\
\text { sprzęt elektryczny } \\
\text { i elektrotechniczny }\end{array}$ & 127,8 & 38,2 & $\begin{array}{l}\text { XVI Maszyny i urządzenia, } \\
\text { sprzęt elektryczny } \\
\text { i elektrotechniczny }\end{array}$ & 502,9 & 45,1 \\
\hline $\begin{array}{l}\text { VI Produkty przemysłu } \\
\text { chemicznego }\end{array}$ & 37,7 & 11,3 & VIII Skóry i artykuły z nich & 230,9 & 20,7 \\
\hline $\begin{array}{l}\text { XV Metale nieszlachetne } \\
\text { i artykuły z nich }\end{array}$ & 28,3 & 8,4 & $\begin{array}{l}\text { XVII Pojazdy i sprzęt } \\
\text { transportowy }\end{array}$ & 74,6 & 6,7 \\
\hline $\begin{array}{l}\text { V Produkty mineralne } \\
\text { Xrodury }\end{array}$ & 25,3 & 7,6 & $\begin{array}{l}\text { XX Artykuły przemysłowe } \\
\text { różne - meble, prefabrykaty } \\
\text { budynków, zabawki itp. }\end{array}$ & 55,6 & 5,0 \\
\hline $\begin{array}{l}\text { XVII Pojazdy i sprzęt } \\
\text { transportowy }\end{array}$ & 18,7 & 5,6 & $\begin{array}{l}\text { XVIII Przyrzady i aparatura, } \\
\text { optyczne, fotograficzne, } \\
\text { pomiarowe, kontrolne itp. }\end{array}$ & 52,4 & 4,7 \\
\hline
\end{tabular}

Źródło: opracowanie własne na podstawie [GUS 2016].

Eksport do Kanady zdominowany jest przez wyroby elektromaszynowe (ponad $45 \%$ całego polskiego eksportu do Kanady stanowią towary sekcji XVI, przy czym kluczową pozycją towarową są silniki turboodrzutowe, turbośmigłowce oraz inne turbiny gazowe - $\mathrm{CN} 8411$ ). Kolejne pozycje (agregowane na poziomie czterocyfrowych kodów $\mathrm{CN}$ ) zajmują: surowe skóry futerkowe (CN4301), części szybowców i samolotów (CN 8803), sprzęt i aparaty ortopedyczne, protezy, aparaty słuchowe (CN9021) oraz meble (bez mebli do siedzenia i lekarskich) i ich części (CN9403) [GUS 2016]. Podobnie jak w eksporcie, w imporcie z Kanady również dominują wyroby przemysłu elektromaszynowego, a istotną drugą pozycję zajmują produkty przemysłu chemicznego. Jeśli chodzi o główne towary importowane, są to: elektroniczne układy scalone (CN8542); wały napędowe, korby, obudowy łożysk, łożyska ślizgowe, przekładnie zębate itp. (CN8483); silniki turboodrzutowe, turbośmigłowce oraz inne turbiny gazowe (CN 8411); rudy i koncentraty żelaza (CN2601) oraz leki (CN3003, CN3004) [GUS 2016].

$\mathrm{Na}$ Kanadę należy spojrzeć jednak również z punktu widzenia jej pozycji jako partnera Polski poza granicami UE - wówczas Kanada zajmie miejsce 11. w gronie największych partnerów handlowych Polski. W przypadku wymiany usługowej będzie to miejsce 10. W obrocie usługami między Polską a Kanadą dominują: usługi doradcze związane z zarządzaniem; usługi w zakresie technologii informacyjno-komunikacyjnych; usługi architektoniczne, inżynierskie oraz naukowe. W roku 2015 wywóz usług z Polski do Kanady wyniósł 244,6 mln EUR, natomiast przywóz 
z Kanady do Polski zamknął się kwotą 105,3 mln EUR. Podkreślenia wymaga również fakt, że w odniesieniu do wartości eksportu Polska wyprzedzała członków UE z EŚW, a jej udział określić można jako stabilny (w granicach ok. 1\%) [The EU-Canada...; Analiza...., s. 11].

Polska, jako członek UE stosunkowo odporny na globalne spowolnienie gospodarcze, jest postrzegana przez rząd Kanady ${ }^{6}$ jako atrakcyjne miejsce do lokowania inwestycji. Kanadyjskie BIZ w Polsce wyniosły w 2015 r. ponad $280 \mathrm{mln}$ EUR (niespełna $0,2 \%$ ogółem wszystkich BIZ w Polsce). Z kolei polskie BIZ w Kanadzie w 2015 r. osiągnęły wartość prawie 690 mln EUR (czyli ponad 3\% polskich BIZ za granicą). Polskie przedsiębiorstwa prowadzą działalność inwestycyjną w Kanadzie m.in. w obszarach górnictwa, wydobycia ropy naftowej i gazu. Z kolei kanadyjscy inwestorzy w Polsce zainteresowani są głównie branżami IT, B\&R oraz lotniczą [The EU-Canada..., s. 9].

\section{Wnioski - perspektywy rozwoju polsko-kanadyjskich stosunków handlowych w świetle zapisów CETA}

Przedstawiona analiza obrotów handlowych Polski z Kanadą pokazała, że chociaż Kanada nie należy do grona kluczowych partnerów handlowych Polski, to jednak notowany systematyczny wzrost wymiany handlowej, wsparty wynikającą z zapisów umowy całkowitą eliminacją lub sukcesywną obniżką stawek celnych oraz liberalizacją innych barier o charakterze pozataryfowym na towary zajmujące kluczowe miejsce w dwustronnej wymianie handlowej, może w istotny sposób przyczynić się do umocnienia wzajemnych relacji handlowych, wpłynąć na wzrost obrotów i przynieść korzyści polskim eksporterom.

CETA została ratyfikowana przez Parlament Europejski w połowie lutego 2017 r. 21 września 2017 r. weszła w życie i jest stosowana tymczasowo w części handlowej. Całe porozumienie, łącznie z częścią inwestycyjną, będzie obowiązywało po zakończeniu ratyfikacji przez parlamenty poszczególnych krajów UE. Umowa składa się z 30 rozdziałów oraz precyzujących szczegóły licznych załączników, które obejmują prawie 900 stron. Poniższa analiza została przeprowadzona w oparciu o wybrane zapisy CETA?

Zapisane $\mathrm{w}$ umowie zniesienie taryf celnych $^{8}$ odnosi się praktycznie do całego eksportu Polski. Wartość wywozu maszyn i urządzeń elektrycznych do Kanady

${ }^{6}$ Global Markets Action Plan na lata 2015-2017 wskazuje na Polskę jako na rynek bardzo ważny dla Kanady ze względu na m.in.: wielkość tego rynku, pozycję w UE czy przyjazny klimat inwestycyjny. Por.: [Poland: Market Access Plan 2015-2017].

${ }^{7}$ Szczegółowa analiza umowy, na której Autorka oparła również badania znajdujące się w tej części opracowania, została zawarta w: [Majchrowska 2017].

${ }^{8}$ Prawie wszystkie cła na towary przemysłowe zostaną zniesione, przy czym od momentu obowiązywania umowy - na 99,6\% towarów importowanych do Kanady i 99,3\% w imporcie do UE. Od momentu wejścia w życie umowy Kanada wyeliminuje cła na 90,9\% towarów rolnych, a po zakoń- 
w roku 2015 wyniosła prawie $503 \mathrm{mln}$ EUR, co stanowi blisko połowę wielkości wywozu z Polski do Kanady ogółem oraz prawie $6 \%$ całkowitej wielkości unijnego wywozu do Kanady w odniesieniu do tego sektora. Mimo że produkty tej sekcji objęte są stosunkowo niskimi średnimi stawkami celnymi, to jednak w odniesieniu do niektórych z nich taryfy celne sięgają nawet $9 \%$. Należy podkreślić, że szczególne znaczenie dla polskich przedsiębiorców będzie miała jednak eliminacja kosztów podwójnego testowania, co wynika z postanowień związanych z uznawaniem świadectw oceny zgodności w sektorach: maszynowym, towarów elektrycznych oraz sprzętu elektronicznego9. Ponadto sektory te mogą odnieść korzyści wynikające $\mathrm{z}$ udzielania zamówień publicznych ${ }^{10}$ oraz przepływu specjalistów [The EU-Canada..., s. 7]. Polska zajmuje pozycję lidera w zakresie eksportu do Kanady wyrobów działu 43. sekcji VIII (szczególnie surowych skór futerkowych). Eksport polskich futer stanowi praktycznie całość wywozu futer z UE do Kanady - w roku 2015 udział ten wynosił ponad 96\% (ponad $232 \mathrm{mln}$ EUR). Należy podkreślić, że kanadyjska taryfa celna przewiduje w tym zakresie stawki maksymalne na poziomie $9 \%$. Jeśli chodzi o meble - udział na poziomie 13\% w całym handlu UE wyrobami działu 93 - wywóz z Polski do Kanady wyniósł w 2015 r. prawie 54 mln EUR. W tym zakresie kanadyjskie stawki celne osiągają poziom do $8 \%$ [The EU-Canada..., s. 3]. Ich eliminacja z pewnością będzie korzystna dla polskich eksporterów.

Mimo notowanego w ostatnich latach wzrostu wymiany pozycja Kanady w handlu rolno-spożywczym Polski nie jest znacząca. Wśród czynników wpływających negatywnie na dwustronne obroty handlowe wymienia się znaczny dystans geograficzny, położenie partnerów w podobnej strefie klimatycznej, wpływające na zbliżoną strukturę produkcji, oraz specyfikę genetycznie modyfikowanych kanadyjskich upraw. Jeśli chodzi o import z Kanady (w roku 2016 wzrost na poziomie 0,7\% w stosunku do roku poprzedniego), nie jest spodziewana istotna zmiana po wejściu w życie zapisów umowy CETA, gdyż na główne grupy towarowe były już stosowa-

czeniu 7-letniego okresu przejściowego - 91,7\%. Wskaźniki te dla Unii Europejskiej kształtują się odpowiednio na poziomie $92,2 \%$ i 93,8\%. Harmonogramy redukcji ceł importowych zostały uwarunkowane poziomem wrażliwości towarów. W umowie CETA, inaczej niż w dotychczasowych umowach handlowych UE, plany redukcji zostały ujęte w postaci tzw. listy negatywnej, co oznacza całkowitą natychmiastową liberalizację ceł we wszystkich liniach taryfowych poza tymi, które zostały wskazane przez strony w listach koncesyjnych. Przewidziano dla nich kilka kategorii znoszenia ceł. Por. szerzej: [CETA 2017, Znoszenie ceł: Zał. 2-A; Majchrowska 2017].

${ }^{9} \mathrm{~W}$ odniesieniu do oceny zgodności strony umowy zobowiązały się do przestrzegania Protokołu w sprawie wzajemnej akceptacji wyników oceny zgodności [Protocol...], który przewiduje mechanizm umożliwiający europejskim jednostkom certyfikującym (według zasad stosowanych w Kanadzie) certyfikowanie produktów na rynek kanadyjski zgodnie z kanadyjskimi przepisami technicznymi, i odwrotnie, w celu obniżenia kosztów związanych z testowaniem (w szczególności na skutek unikania podwójnych testów). Por.: [Analiza..., s. 28].

${ }^{10}$ Przedsiębiorstwa z UE będą pierwszymi przedsiębiorstwami zagranicznymi, które uzyskają dostęp do kanadyjskiego rynku zamówień publicznych w takim zakresie, jaki nie jest zapisany w żadnej innej umowie międzynarodowej zawartej przez Kanadę, w tym GPA II i NAFTA. 
ne stawki zerowe. Dotyczy to głównie: karmy dla psów i kotów, pszenicy durum, nasion gorczycy, lnu i soi, soczewicy czy mrożonego mięsa. Niewielka też będzie obniżka cła w imporcie mrożonych filetów z łososi (cło KNU stosowane w 2014 r. wynosiło $2 \%$, po wejściu w życie umowy - 0\%). Istotne będą natomiast obniżki stawek celnych w imporcie syropów cukrowych i syropu klonowego (cło KNU do $12,8 \%$ ), żurawiny i borówki amerykańskiej oraz przetworów z nich ${ }^{11}$ (cło KNU do 17,6\%), jaj indyczych lub gęsich (105 EUR/1000 szt.) czy grzybów (12,8\%) i krewetek (12\%). Niewielkie znaczenie w otwarciu unijnego, w tym polskiego, rynku będą też miały bezcłowe kontyngenty taryfowe na wieprzowinę i wołowinę, gdyż Kanada nie wykorzystywała nawet kontyngentów WTO ${ }^{12}$ [Informacyjny System...; Analiza..., s. 85].

Wśród głównych pozycji towarowych w polskim eksporcie do Kanady (agregowanych na poziomie 4-cyfrowych kodów CN) w 2015 r. znalazły się: czekolada i inne przetwory spożywcze zawierające kakao (CN 1806); mięso wieprzowe świeże, schłodzone lub zamrożone (CN 0203); wyroby cukiernicze niezawierające kakao (CN 1704); soki owocowe i warzywne (CN 2009); wódki, likiery, inne napoje alkoholowe o mocy poniżej 80\% (CN 2208); piwo (CN 2203); warzywa zamrożone (CN 0710); owoce zamrożone (CN 0811); sosy; mieszanki przyprawowe; musztarda (CN 2103); sery i twarogi (CN 0406) [GUS 2016].

Tabela 4. Wartość polskiego eksportu artykułów rolnych do Kanady dla dziesięciu głównych pozycji towarowych (wg kodów CN, mln USD, 2015 r.)

\begin{tabular}{|c|c|c|c|c|c|c|c|c|c|c|}
\hline Kod CN & 1806 & 0203 & 1704 & 2009 & 2208 & 2203 & 0710 & 0811 & 2103 & 0406 \\
\hline Wartość & 15,2 & 10,9 & 6,6 & 6,2 & 4,8 & 4,2 & 3,5 & 3,1 & 2,3 & 2,2 \\
\hline
\end{tabular}

Źródło: opracowanie własne na podstawie [GUS 2016].

Analizując harmonogramy obniżek bądź eliminacji stawek celnych na główne towary w polskim eksporcie, należy zauważyć, że na część z nich obowiązują stawki zerowe - dotyczy to głównie piwa, boczku wieprzowego oraz filetów z łososia i głowacicy. W tym zakresie umowa CETA nie przyniesie zmian. Jeśli chodzi o zmiany w kanadyjskiej taryfie, istotne znaczenie będzie miało natomiast szczególnie zniesienie ceł na: czekoladowe wyroby cukiernicze - dominujące w pozycji CN1806 na które kanadyjskie stawki celne wynoszą do 6\%; sok jabłkowy (CN 2009) - stawki do 8\%; wódkę (CN 2208) podlegającą cłu specyficznemu 12,28 centa CAD za litr bezwodnego alkoholu etylowego. W przywozie do Kanady liberalizacją nie zostaną objęte (poza wprowadzanymi stopniowo kontyngentami), uznane za najbardziej

${ }^{11}$ Pewnym zagrożeniem dla krajowych producentów może być import borówki amerykańskiej, gdyż już od pewnego czasu obserwuje się w Polsce dynamiczny rozwój jej produkcji.

12 UE importuje wołowinę głównie z krajów Ameryki Południowej. Zwiększenie przywozu z Kanady musiałoby wiązać się z zakazem stosowania chlorowodorku raktopaminy oraz ze zwiększeniem liczby rzeźni spełniających unijne standardy w tym zakresie. 
wrażliwe, a istotne z punktu widzenia Polski, jedynie ser i twaróg [CETA 2017, Znoszenie ceł: Zał. 2-A, pkt 16].

Podsumowując, CETA przewiduje znaczne obniżki stawek celnych w imporcie do Kanady w przypadku dość dużej grupy produktów istotnych z punktu widzenia polskich eksporterów. W przypadku niektórych z nich ${ }^{13}$ obniżka ta może sięgać nawet kilkunastu punktów procentowych, co z pewnością przyczyni się do poprawy konkurencyjności cenowej na kanadyjskim rynku produktów polskich w stosunku zarówno do produktów krajowych, jak i przywożonych spoza Unii. Należy jednak pamiętać, że w przypadku wielu produktów decydować będą również bariery o charakterze pozataryfowym, co dotyczyć może np. alkoholi ${ }^{14}$ [Analiza..., s. 88; Rynek produktów alkoholowych ...]. Należy również podkreślić, że prawie $90 \%$ polskiego eksportu dociera do prowincji Ontario i Quebec, stąd istotne wydaje się również rozwijanie współpracy z innymi prowincjami (mając jednak na uwadze zróżnicowane wymogi w zależności od prowincji) ${ }^{15}$, co również może przyczynić się dalszego rozwoju wzajemnych stosunków handlowych, zwłaszcza po stronie polskiego eksportu.

Jeśli chodzi o usługi ${ }^{16}$, CETA wpłynie na poprawę oraz zabezpieczenie dostępu do kanadyjskiego rynku usług [CETA 2017, art. 9.6], co wynikać będzie m.in. $\mathrm{z}$ eliminacji szeregu ograniczeń ${ }^{17}$ oraz zwiększenia poziomu otwartości w stosunku do przedsiębiorstw z UE ${ }^{18}$. Polskie przedsiębiorstwa otrzymają również dostęp do kanadyjskiego rynku zamówień publicznych, co będzie wiązało się z możliwością składania ofert na dostawy towarów i usług na wszystkich poziomach rządowych w Kanadzie. Ponadto CETA ułatwi polskim przedsiębiorcom dokonywanie inwestycji w Kanadzie ${ }^{19}$ - po pełnym wejściu w życie zastąpi ona dwustronną umowę in-

\footnotetext{
${ }^{13} \mathrm{~Np}$. w przypadku papierosów zawierających tytoń (CN 2402(20)) cło KNU w 2014 r. wynosiło $12,5 \%$, po wejściu w życie umowy - $0 \%$. Wartość polskiego eksportu do Kanady towarów z pozycji CN 2402 (cygara, cygaretki i papierosy) wyniosła w 2015 r. 1,4 mln USD.

${ }^{14} \mathrm{Z}$ punktu widzenia polskich eksporterów wódki, oprócz zniesienia ceł istotne znaczenie będzie miała również eliminacja innych barier. Dotyczyć to będzie m.in zmiany w naliczaniu opłat z tytułu różnic w koszcie usługi nakładanej przez komisje na poziomie prowincji czy zniesienia wymogu mieszania wódek (przywożonych luzem) z lokalnymi przed butelkowaniem (uniemożliwiało to etykietowanie produktów klasyfikowanych jako oznaczenia geograficzne). Por.: [The EU-Canada..., s. 4-5].

${ }^{15}$ CETA uwzględnia specyfikę i odmienność regulacji prawnych przyjętych w poszczególnych regionach Kanady jako państwa o ustroju federalnym, co może wiązać się także z pewnymi ograniczeniami w odniesieniu do handlu usługami i przepływów inwestycyjnych.

${ }^{16}$ Podobnie jak w przypadku towarów przyjęta „lista negatywna” oznacza liberalizację wszystkich usług z wyjątkiem tych wyraźnie wyłączonych [CETA 2017, rozdział 9].

${ }^{17}$ Chodzi głównie o ograniczenia dotyczące obywatelstwa i pobytu w zakresie prowadzenia praktyki w Kanadzie przez prawników, księgowych czy architektów. Postanowienia umowy mają również ułatwić podejmowanie pracy w Kanadzie polskim specjalistom (i odwrotnie) m.in. poprzez uznawanie kwalifikacji. Por.: [CETA 2017, Zał. 1-A; The EU-Canada..., s. 6].

${ }^{18} \mathrm{~W}$ odniesieniu $\mathrm{np}$. do usług finansowych, pocztowych, kurierskich czy telekomunikacyjnych. Por. m.in.: [CETA 2017, Zał. 13-A].

${ }_{19}$ Wiąże się to m.in. ze znacznym podwyższeniem progu związanego z kontrolą nabywania kanadyjskich przedsiębiorstw przez przedsiębiorstwa niekanadyjskie. Por.: [The EU-Canada..., s. 9].
} 
westycyjną z 1990 r. [Dz.U. z 1991, nr 27, poz. 114] oraz przyczyni się do większej przejrzystości, przewidywalności oraz ochrony w tym zakresie.

Omówione dziedziny współpracy wydają się obiecujące, a stanowisko Kanady, dotyczące dywersyfikacji rynków eksportowych i importowych, związane z chęcią uniezależnienia się, przynajmniej częściowego, od gospodarki amerykańskiej, powinno zostać wykorzystane przez unijnych, w tym polskich przedsiębiorców. Szacuje się, że korzystne warunki do dalszego pogłębiania współpracy gospodarczej oraz wymiany handlowej Polski z Kanadą istnieją szczególnie w ramach: przemysłu lotniczego, mechanizmów i przekładni, energetyki, w dziedzinie przemysłu obronnego, branży budowlanej, mebli, ale również eksportu polskiej żywności na rynek kanadyjski [Ministerstwo Rozwoju 2017]. Należy również pamiętać, że korzystne dla stron umowy postanowienia dotyczące kwestii fitosanitarnych, weterynaryjnych i innych barier o charakterze technicznym w handlu zapewniają utrzymanie dotychczasowego poziomu ochrony unijnych obywateli, który nie zostanie osłabiony [CETA 2017, rozdział 5 oraz 25].

Powyższa analiza pozwala zatem na stwierdzenie, iż istnieją znaczące możliwości rozwoju polsko-kanadyjskich stosunków handlowych, a wejście w życie postanowień omawianego porozumienia $\mathrm{z}$ pewnością będzie szansą dla unijnych, w tym polskich, producentów. Potwierdzają to również wyniki badań, które wskazują, że wzajemne otwarcie rynków na produkty, usługi i inwestycje partnera, w tym poprzez zamówienia publiczne, będzie bardzo korzystne dla stron umowy. Przeprowadzona ocena rezultatów z 2008 r. wskazuje, że roczny wzrost dochodu w ujęciu realnym w okresie siedmiu lat od rozpoczęcia realizacji umowy może wynieść nawet 11,6 mld EUR w przypadku UE oraz 8,2 mld EUR w przypadku Kanady [Assessing the costs..., s. vi].

\section{Literatura}

Analiza gospodarczo-handlowa Całościowego Gospodarczego i Handlowego Porozumienia z Kanadą (CETA) dla polskiej gospodarki i przedsiębiorców - wybrane zagadnienia, Ministerstwo Rozwoju, Warszawa 2016, https://www.mr.gov.pl/media/28076/Analiza_CETA1.pdf (15.07.2017).

Assessing the costs and benefits of a closer EU-Canada Economic Partnership. A Joint Study by the European Commission and the Government of Canada, http://trade.ec.europa.eu/doclib/docs/2008/october/tradoc_141032.pdf(12.07.2017).

CETA, 2017, Kompleksowa Umowa Gospodarczo-Handlowa między Kanadą, z jednej strony, a Unią Europejską i jej państwami członkowskimi, z drugiej strony, Dz.Urz. UE L 11 z 14.1.2017, http://eur-lex.europa.eu/legal-content/PL/TXT/PDF/?uri=CELEX:22017A0114(01)\&from=EN (10.06.2017).

DG Trade, CETA - Summary of the final negotiating results, December 2014, s. 2-3, http://trade.ec.europa.eu/doclib/docs/2014/december/tradoc_152982.pdf(15.07.2017).

Dz.U. z 1991 r., nr 27, poz. 114, Umowa między Rządem RP a Rządem Kanady w sprawie popierania i wzajemnej ochrony inwestycji podpisana w Warszawie w dniu 6 kwietnia 1990 r. 
Eksport do Kanady artykułów spożywczych, Wydział Promocji Handlu i Inwestycji Konsulatu Generalnego RP w Montrealu, 2015, https://canada.trade.gov.pl/pl/ (10.09.2017).

European Commission, 2014, DG Trade, CETA - Summary of the final negotiating results, December 2014, s. 2-3, http://trade.ec.europa.eu/doclib/docs/2014/december/tradoc_152982.pdf(15.08.2017).

European Commission, 2017, DG Trade, Client and Supplier Countries of the EU28 in Merchandise Trade, http://trade.ec.europa.eu/doclib/docs/2006/september/tradoc_122530.02.2017.pdf (15.08.2017).

GUS, 2016, Rocznik statystyczny handlu zagranicznego, Zakład Wydawnictw Statystycznych, Warszawa. Informacyjny System Zintegrowanej Taryfy Celnej, https://ext-isztar4.mf.gov.pl/taryfa_celna/browseNomen.$x h t m l$ cnCode $=170220 \&$ suffix $=80 \&$ lang $=P L \&$ page $=1 \&$ date $=20170626 \&$ cssfile $=$ tarbro (5.06.2017).

Insigos 2017, https://insigos.mg.gov.pl/Glowna.aspx (10.05.2017).

Ministerstwo Rozwoju, 2017, KANADA - Informacja o stosunkach gospodarczych Polski, https://www. mr.gov.pl/media/32023/Kanada_18_01_2017.pdf (15.06.2017).

MADB, Market Access Database, http://madb.europa.eu/madb/statistical_form.htm (25.07.2017).

Majchrowska E., 2017, The trade aspects of the transatlantic cooperation between the EU, the USA and Canada, Krakowskie Studia Międzynarodowe, 2 (w druku).

Ministerstwo Rozwoju 2017, Kanada. Informacja o stosunkach gospodarczych Polski, https://www. mr.gov.pl/media/41175/Kanada_19_07_2017.pdf(15.09.2017).

Ocena sytuacji w handlu zagranicznym w 2016 roku, Ministerstwo Rozwoju, Departament Strategii Rozwoju, https://www.mr.gov.pl/media/34776/Ocena_sytuacji_w_handlu_zagranicznym_2016. pdf (15.07.2017).

Poland: Market Access Plan 2015-2017, http://international.gc.ca/global-markets-marches-mondiaux/ markets-marches/map_poland-pam_pologne.aspx?lang=eng (02.09.2017).

Protocol on the mutual acceptance of the results of conformity assessment, https://ec.europa.eu/transparency/regdoc/rep/1/2016/EN/1-2016-443-EN-F1-1-ANNEX-8.PDF (15.06.2017).

Rynek produktów alkoholowych w Kanadzie, Wydział Promocji Handlu i Inwestycji Konsulatu Generalnego RP w Montrealu, 2015, https://canada.trade.gov.pl/pl/ (10.09.2017).

The EU-Canada Comprehensive Economic and Trade Agreement (CETA), http://trade.ec.europa.eu/ doclib/docs/2017/february/tradoc_155355.pdf(10.06.2017).

World Tariff Profiles 2010, https://www.wto.org/english/res_e/booksp_e/tariff_profiles10_e.pdf (22.06.2017).

World Trade Statistical Review, 2016, https://www.wto.org/english/res_e/statis_e/wts2016_e/wts 2016_e.pdf(10.06.2017).

WTO, Facts and figures, https://www.wto.org/english/tratop_e/region_e/regfac_e.htm (15.06.2017).

WTO, Regional trade agreements, https://www.wto.org/english/tratop_e/region_e/region_e.htm (25.06.2017).

WTO, RTA-IS, http://rtais.wto.org/UI/PublicMaintainRTAHome.aspx (10.06.2017). 